\title{
European Experience of Clustering and Its Adaptation Towards Acceleration of Innovative Development of the Economy of Ukraine
}

\author{
Mykola Butko \\ Department of Management and Public \\ Administration \\ Chernihiv National University of Technology \\ Chernihiv, Ukraine \\ http://orcid.org/0000-0002-8628-9444 \\ Galyna Samiilenko \\ Department of Management and Public \\ Administration \\ Chernihiv National University of Technology \\ Chernihiv, Ukraine \\ http://orcid.org/0000-0001-6844-647X
}

\author{
Svitlana Povna \\ Department of Management and Public \\ Administration \\ Chernihiv National University of Technology \\ Chernihiv, Ukraine \\ http://orcid.org/0000-0002-0654-9868
}

\author{
Olha Popelo \\ Department of Management and Public \\ Administration \\ Chernihiv National University of Technology \\ Chernihiv, Ukraine \\ http://orcid.org/0000-0002-4581-5129
}

\begin{abstract}
It was identified within the study, that in $E U$ countries the level of cluster development in most cases correlates with the ranking of countries by the degree of innovation. Based on the results of the analysis of the existing international methodologies for cluster development assessment, the author's approach was proposed to identify and structure the goals of creating industrial and innovation clusters. Considering that in Ukraine the indicators of enterprise innovation activity have been declining during 2011-2017, it is suggested that more emphasis in domestic practice should be made on the creation of innovative clusters, which will contribute to the formation of stable links between enterprises among themselves, as well as with the sphere of innovation infrastructure, which are based on the latest knowledge.
\end{abstract}

Keywords - Cluster, Clusterization, Innovation Development, Production Cluster, Innovation Cluster

\section{INTRODUCTION}

The theory substantiates, that clusters arise at the geographical concentration of manufacturers of a certain industry with supporting industries, namely, local suppliers of equipment and materials, as well as services and infrastructure. A whole subculture of mutual support, which is the most stable competitive advantage, is developed within the cluster [1].

In recent years, a number of European countries have accumulated the experience of successful stimulation of the innovation development within clustered industrial systems (Nordic countries, Italy, Germany, France, Australia, Slovenia, etc.). The world practice shows that during the last 20 years the process of cluster formation has been very intense and gains progressive momentum. In general, according to experts, to date clusterization has covered about $50 \%$ of the economies of the leading countries of the world; this tendency is underlined by many scientists [2-4]. Analysis of clustering allows you to distinguish its main features: active promotion and dissemination of this process and permanent growth of cluster structures; growth of interest and taking part in the cluster's activities on the part of the authorities; a large number of different models of clusters and the lack of common and generally accepted approaches and schemes for the creation and development of cluster entities.

\section{ANALYSIS OF RECENT RESEARCH AND PUBLICATIONS}

There are several scientists who are investigating the industrial clusters, among them are O'Connor J. [5], Gu X. [5], Qiang Liu [6], Jiafu Wan [6], Gebhardt Ch. [7], Cheng H. [8], Ming-Shan Niu [8], Kozhukhivska R. [9], Jiang Lan [10], Wang Chengjun [10], Zhang Wei [10], Sonobe T. [11], Keijiro O. [11], Chetty S. [12], Agndal H. [12], Hoffman V.E. [13], Lopes G.S. [13], Medeiros J.J. [13].

Authors of the study O'Connor J., Gu X. examines the development of creative industry clusters in Shanghai. It looks at the cautious adoption of the creative industries' agenda by the Chinese government and how Shanghai was to adopt this more positively. The paper also looks at the complex provenance of the creative cluster's concept and how Shanghai focused more on its urban regeneration effects rather than its role as 'industry base'. They try to show how the creative industries' agenda, viewing this sector as advanced business services, allowed creative clusters to be linked to a powerful real estate model [5].

Qiang Liu, Jiafu Wan, Keliang Zhou researched, that such modern technology and business demands as information sharing, design, outsourcing manufacture, orders collaborating, etc., among enterprises and factories in the industrial cluster area, ask for public technology supports and services. Recently, Cloud Manufacturing Service System (CMSS) is a novelty way to provide open and generalized manufacturing services [6].

The paper of Swiss scientist Christiane Gebhardt demonstrates the importance of consideration of organizational development in Triple Helix constellations and supports arguments in favor of good cluster governance in Triple Helixbased regional innovation systems [7]. 
The primary purpose of the study conducted by the scientists Hilary Cheng, Ming-Shan Niu, Kuei-Hsien Niu (from Taiwan and USA) is to examine the relationships among an enterprise industrial cluster involvement, organizational learning and its ability to successfully adapt to the external environment. Further, the study attempts to empirically examine learning and cluster involvement in relation to organizational adaptation [8].

According to the research of Raisa Kozhukhivska, Nataliya Parubok, Nataliya Petrenko, Svitlana Podzihun and Irina Udovenko into the methods of estimating the efficiency of creating regional innovation clusters for dynamic development of economics, it was established that the application of an innovative cluster approach is one of the most efferent tools in the process of fulfilling the tasks of enterprises modernization and ensuring the development of innovative sectors of economy. The external effect for regional authorities is the increase in the taxation basis due to locating additional enterprises in the region and intensification of innovation processes, reduction of prime cost of the produced output, increase of profitability and improvement of socioeconomic situation for the population of the region [9].

Scientists Jiang Lan, Wang Chengjun and Zhang Wei consider that continuous industrial development will inevitably form an agglomeration effect after reaching a certain level. When the industrial agglomeration effect appears, the growth of the industry will be stimulated, and it would cause further optimization and upgrading, thereby attracting the relevant industry chain to achieve the scale and efficiency, and finally, the phenomenon of industrial clusters will be achieved. The advantages of industrial clusters relative to industrial competition lie in the benefits of industrial economies in clusters, and their good influence on the economic development of clusters and surrounding areas. Therefore, all countries in the world are very concerned about the development and research of industrial clusters [10].

Authors Sonobe T., Keijiro O. analyzes in their book the dynamic process of industrial development involving imitation and innovation. The authors pay particular attention to the significance of industrial clusters consisting of a large number of small and medium-sized enterprises within a specific location. While the phenomenon of clustering of industries itself is a matter of interest (i.e., "why do industries tend to agglomerate?"), most of the economic studies do not examine deeply such important issues as: "what is going on in industrial clusters?", "how do industrial clusters are beneficial to the economic development?" and "what should we do about industrial clusters?" This study makes a substantial contribution to fulfill such a gap with rigorous empirical analyses based on the rich data obtained from extensive field research in Japan, Taiwan, and China [11].

Chetty Sylvie and Agndal Henrick revealed that the industrial cluster had been used by small- and medium-sized enterprises (SMEs) to expand their international markets, develop innovative products and marketing strategies, as well as to identify business opportunities [12].
The work of Hoffman V.E., Lopes, G.S.C., Medeiros J.J. shows how knowledge is shared among small businesses operating in industrial clusters and how this competitive resource circulates and accesses within the cluster. Interfirm cooperation, industrial support institutions, workforce mobility, and social ties were used to structure the survey instrument as concepts highlighted in the literature as dimensions of the knowledge transfer process [13].

\section{MAIN PART}

When examining clustering and innovation processes, an important issue about their interconnection is raised. Therefore, in carrying out analytical and statistical studies, attention is drawn to the active involvement of cluster companies in innovation activities. According to the EU studies as for the role of clusters in the innovation development, it can be argued that the innovative activity of cluster companies is about $60 \%$, and about $40-45 \%$ of the companies outside clusters [14].

One of the results of the development of clusters and the activity of business support structures at the degree of the European Union is the growth of the overall innovation potential of the EU as a whole (Table 1) [15, 16, 17].

In-Depth analysis demonstrates correlation dependence between innovation and clustering development of EU countries. Therefore, as one of the main tools for strengthening the innovative component of the EU, experts suggest intensifying the development of innovative clusters, understanding them as "cores" of the future knowledge economy, as noted in the Covenant on Research and Innovation, which summarizes proposals of the expert group [18].

However, it should be noted that there are exceptions when a country with a high ranking cluster development is a part of a weaker innovation group (Germany, Italy, and Bulgaria). Conversely, countries with low cluster development are part of a stronger innovation group of countries (Slovenia, Greece, and Croatia).

The need to increase the level of innovation activity of enterprises is extremely important for Ukraine (Table 2).

The characteristic is that in Ukraine, the share of implemented innovative products, new for the market (i.e. of high level), for 2011-2017 fluctuated at the level of 20-27\% with a tendency to decrease. The only indicators of the implementation of a low waste, resource-saving and non-waste technological processes increased significantly (+18.2\%), which can be attributed to a significant rise in the cost of energy resources, while the overall introduction of new technological processes decreased by $27.1 \%$.

However, clusterization does not always bring with it an increase in the level of innovation. According to studies, horizontal connections between competing enterprises in the cluster do not help to find innovative solutions, and the transmission of information through vertical links between suppliers and consumers in the cluster provides an opportunity for the growth of the innovative level of partners [20]. 
TABLE I. GROUPING OF EU COUNTRIES ACCORDING TO THE DEGREE OF INNOVATION DEVELOPMENT AND THEIR PLACE IN THE RANKING OF CLUSTER DEVELOPMENT, 2018

\begin{tabular}{|c|c|c|}
\hline $\begin{array}{l}\text { Groups of countries } \\
\text { according to the } \\
\text { degree of innovative } \\
\text { development }\end{array}$ & European countries & $\begin{array}{c}\text { Ranking of countries } \\
\text { in terms of cluster } \\
\text { development (state of } \\
\text { cluster development) } \\
\text { within GCI WE }\end{array}$ \\
\hline \multirow{6}{*}{ Innovation leaders } & Netherlands & 6 \\
\hline & UK & 10 \\
\hline & Sweden & 13 \\
\hline & Austria & 15 \\
\hline & Finland & 18 \\
\hline & Denmark & 20 \\
\hline \multirow{5}{*}{ Strong Innovators } & Germany & 2 \\
\hline & Belgium & 17 \\
\hline & France & 21 \\
\hline & Ireland & 24 \\
\hline & Slovenia & 60 \\
\hline \multirow{14}{*}{ Moderate innovators } & Italy & 4 \\
\hline & Spain & 37 \\
\hline & Portugal & 38 \\
\hline & Malta & 42 \\
\hline & Czech Republic & 47 \\
\hline & Hungary & 65 \\
\hline & Slovakia & 66 \\
\hline & Poland & 67 \\
\hline & Cyprus & 70 \\
\hline & Latvia & 73 \\
\hline & Estonia & 76 \\
\hline & Lithuania & 96 \\
\hline & Greece & 127 \\
\hline & Croatia & 130 \\
\hline \multirow{2}{*}{ Modest Innovators } & Bulgaria & 64 \\
\hline & Romania & 119 \\
\hline
\end{tabular}

In present day environment, the International cluster development estimate is considered in the following rankings: Competitiveness Index and Global Innovation Index.

The Competitiveness Index assesses the level of clusters development by questioning executives of enterprise about how widely they are distributed. Thus, we are talking about the existence of cooperation ties between enterprises of different types, but the level of innovation of these links is not taken into consideration.
TABLE II. DYNAMICS OF KEY PERFORMANCE INDICATORS OF INNOVATION ACTIVITY IN UKRAINE

\begin{tabular}{|c|c|c|c|c|c|}
\hline \multirow{2}{*}{ Indicators } & \multicolumn{4}{|c|}{ Years } & \multirow{2}{*}{$\begin{array}{l}\text { Growth } \\
\text { rates, \%, } \\
2017 / 2011\end{array}$} \\
\hline & 2011 & 2013 & 2015 & 2017 & \\
\hline $\begin{array}{c}\text { Part of industrial enterprises } \\
\text { engaged in innovations, } \% \\
\text { to the total number of } \\
\text { surveyed enterprises }\end{array}$ & 16.2 & 16.8 & 17.3 & 16.2 & 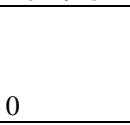 \\
\hline $\begin{array}{c}\text { Introduction of innovative } \\
\text { types of products, items }\end{array}$ & 3238 & 3138 & 3136 & 2387 & -26.3 \\
\hline including: & & & & & \\
\hline new for the market & 900 & 640 & 548 & 477 & -47.0 \\
\hline new only for the enterprise & 2338 & 2498 & 2588 & 1910 & -18.3 \\
\hline $\begin{array}{l}\text { percentage of new for the } \\
\text { market from the total } \\
\text { number of items }\end{array}$ & 27.8 & 20.4 & 17.5 & 20.0 & -7.8 \\
\hline $\begin{array}{l}\text { percentage of new for the } \\
\text { enterprise from the total } \\
\text { number of items }\end{array}$ & 72.2 & 79.6 & 82.5 & 80.0 & +7.8 \\
\hline $\begin{array}{c}\text { Introduction of new } \\
\text { technological processes }\end{array}$ & 2510 & 1576 & 1217 & 1831 & -27.1 \\
\hline $\begin{array}{l}\text { incl. low waste, resource- } \\
\text { saving and non-waste }\end{array}$ & 517 & 502 & 458 & 611 & +18.2 \\
\hline
\end{tabular}

A more detailed assessment is carried out on the basis of the European cluster observatory, at which creation around 2000 clusters were identified as regional agglomerations. For their characteristics at the regional and local levels, such macroeconomic indicators were allocated, as well as the number of employees and their rates, dynamics of enterprise development, relations between employees and enterprises, wages in calculation of operating, size of agglomeration, expert classification, specialization and concentration in a certain sphere of economic activity. Note that they differ significantly from the indicator, which is defined as the main in determining clusters in the Global Innovation Index.

In 2017, the Global Innovation Index made the first attempt to assess subnational innovation clusters, as it is believed that successful formation of such type is necessary to achieve national innovation perfection. The largest clusters are measured by patenting under the Patent Cooperation Treaty, while relying on the mapping methods and patent data of the World Intellectual Property Organization (WIPO). At the same time, it is noted that this estimate is rather complicated, because it lacks the available data [21]. Consequently, when determining clusters by this index, cooperation and interaction at the level of scientific research are mainly taken into consideration, but not cooperation in the production of products, on the basis of which we allocate two types of clusters, namely: production and innovation (Fig. 1).

The objectives of production clusters, in our opinion, can be as follows: improvement of product quality, growth of its market segments, level of price competitiveness of products. The goals of innovative clusters are development and implementation of new types of products, obtaining on this basis additional volumes of exports and increase in considerably increased norms and volumes of profits.

The development of clusters is an important part of the economic development of the EU as a whole and one of the main components of increasing its competitiveness. 


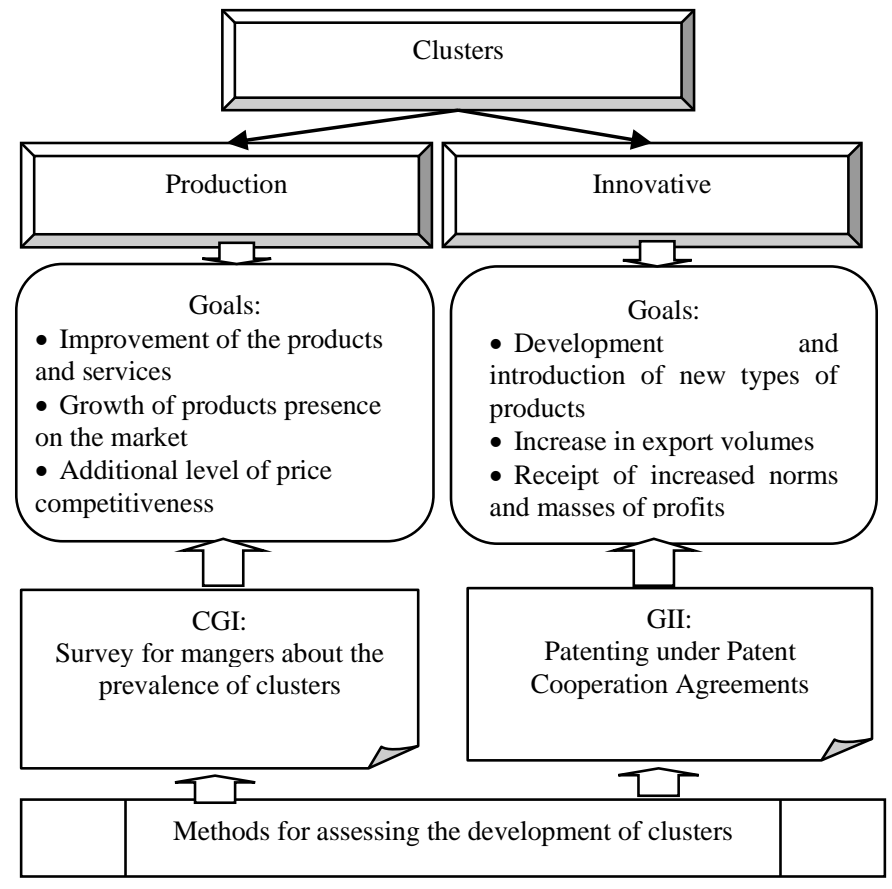

Fig. 1. Types of clusters and methods for their evaluation.

Source: Authors developed

The EU policy supports creation, development and financing of clusters, requiring the Member States to promote cluster policies in national programs to stimulate business [22]. Against the backdrop of the European experience of clustering and innovation, the development of the domestic cluster direction is at the initial stage, and is defined by us as insufficiently developed (Table 3).

Taking into consideration the fact that Ukraine has slightly improved the indicators of cluster development on both indexes during the last years, the situation can be radically changed only in the presence of state or regional programs that motivate business entities to creation and development of production clusters.

In the innovative clusters, which can be technoparks, technopolises, industrial parks, there is a slightly different situation. Nowadays in our state there are the following preferences for the available technoparks (there are registered 16): according to the budget program supporting the technoparks activity, the funds are allocated annually from the state budget of Ukraine for implementation of technology parks projects that are directed towards: (1) full or partial (up to 50\%) interest-free financing (on the basis of inflation indexation) of technopark projects; (2) full or partial compensation of interest paid by the implementors of the technopark projects to commercial banks and other financial and credit institutions for lending into the projects of technoparks. In order to implement the projects, technology parks, their participants and joint ventures, that carry out these projects, are provided by the state with targeted subsidies in the form of import duties for importation of new equipment and components, which are not produced in Ukraine [23].
TABLE III. INTERACTION BETWEEN THE LEVEL OF COMPETITIVENESS, THE LEVEL OF INNOVATION DEVELOPMENT AND THE LEVEL OF CLUSTERS DEVELOPMENT WITHIN THESE INDICES FOR UKRAINE

\begin{tabular}{|c|c|c|}
\hline Indicators & 2017 & 2018 \\
\hline $\begin{array}{c}\text { Global Competitiveness Index } \\
\text { Value } \\
\text { Rank (Ukraine / total number } \\
\text { of countries in the ranking) }\end{array}$ & $\begin{array}{l}4.0 \\
85 / 138\end{array}$ & $\begin{array}{l}4.0 \\
83 / 140\end{array}$ \\
\hline $\begin{array}{c}\text { State of cluster development } \\
\text { (GCI) } \\
\text { Value } \\
\text { Rank }\end{array}$ & $\begin{array}{l}3.0 \\
125\end{array}$ & $\begin{array}{l}3.2 \\
106\end{array}$ \\
\hline $\begin{array}{c}\text { GII } \\
\text { Score } \\
\text { Rank (Ukraine / total number } \\
\text { of countries in the ranking) }\end{array}$ & $\begin{array}{l}37.62 \\
50 / 127\end{array}$ & $\begin{array}{l}38.52 \\
43 / 126\end{array}$ \\
\hline $\begin{array}{c}\text { State of cluster development } \\
\text { (GII) } \\
\text { Score } \\
\text { Rank }\end{array}$ & $\begin{array}{l}32.5 \\
114\end{array}$ & $\begin{array}{l}35.5 \\
98\end{array}$ \\
\hline
\end{tabular}

Monitoring of the readiness to cooperate of 381 Polish companies testified that the cluster process itself does not increase existing innovation potential [24]. Instead, the ability to implement innovation depends entirely on cooperation with other market actors in the direction of information exchange and knowledge that requires trust, without which the cluster becomes dysfunctional.One of the weaknesses of the Polish economy, according to their scholars, is a very low level of trust, without which an effective innovation system cannot be built. This is due to the fact that innovation is largely based on the so-called tacit knowledge. Their role is much higher for innovative processes than the codified ones, which are easy to copy. The results of the study proved a high dependence between the assessment of current cooperation and the possibility of its strengthening in the near future. This gives grounds to state that production clusters in Poland were more developed in comparison with the innovative clusters.

Study of traditional production and innovative cluster structures made it possible to outline their differences. Innovative clusters is a system of close interconnections not only between the business entities, their suppliers and customers, but also the institutes of knowledge, among which there are large research centers and universities. It is education and science, as generators of new knowledge and innovations, that provide a high educational level, form the information potential of integrated activities.

Among the main distinguishing features of the innovation cluster are the following: (1) geographical concentration of enterprises, companies, firms that have advanced technologies, knowledge, information, and organizations that provide for the growth of knowledge distribution among the members of the cluster; (2) close and intense connections (formal and informal), trust, exchange of information, know-how, and technical knowledge within the cluster, which leads to the stimulation and emergence of new unexpected ideas, technological developments and solutions, business ideas, products that enhance the innovation level of the business; (3) presence of stable communication and effective cooperation between the participants of the innovation process in the cluster, which allows to achieve competitive advantages; 
(4) focus on the provision of a range of specific and specialized services (certain auxiliary business services, personnel training, infrastructure provision, etc.) to a specific customer; (5) acceleration of the commercialization of scientific research through activation of venture financing and startups development.

\section{CONCLUSIONS}

Our analysis shows that there is a correlation between innovation and cluster development of the EU countries. However, it should be noted that there are exceptions when a country with a high ranking cluster development is a part of a weaker innovation group (Germany, Italy, Bulgaria). Conversely, countries with low cluster development are part of a stronger innovation groups (Slovenia, Greece, Croatia).

During the research process the GCI and GII estimates for cluster development, we have identified two types of clusters: production and innovation. The goals of the production clusters are as follows: improvement of product quality, growth of its market segments, level of price competitiveness of products. The goals of innovative clusters are development and implementation of new types of products, obtaining on this basis the additional volumes of exports and a considerable increase in norms and volumes of profits.

As Ukraine has indicators of the innovative activity of enterprises, which have significantly deteriorated during 20112017, we believe that it is worth paying more attention to the creation of innovative clusters in a national practice by motivating the formation of stable bonds via state programs that are based on the present knowledge.

\section{REFERENCES}

[1] M. Porter, The Competitive Advantage of Nations. New York: The Free Press, $1990 . \quad$ [Online]. http://www.economie.ens.fr/IMG/pdf/porter_1990_-

the_competitive_advantage_of_nations.pdf. Accessed on: June, 29, 2019

[2] R. V. Mann, "Theoretical and methodological principles of formation of cluster policy”, Chasopy`s ekonomichny`x reform, no.4, pp. 56-61, 2013.

[3] O. O. Plaksyuk, O.V. Finagina, and A. I. Bojko, "Theoretical principles of the cluster economy: the question of balancing and harmonizing economic interests", in Transformations of economic systems: challenges of the present, Cherkasy: ChDTU, 2017, pp. 168-177.

[4] D.V. Solokha, Conceptual bases of formation of the mechanism of economic innovative development of the national economy on the principles of clusterization, Kyiv: KNUKiM, 2017.

[5] J. O'Connor, and X. Gu, "Creative industry clusters in Shanghai: A success story?" International Journal of Cultural Policy, no.20 (1), $2014 . \quad$ [Online]. Available: https://www.tandfonline.com/doi/abs/10.1080/10286632.2012.740025. Accessed on: June, 29, 2019

[6] Q. Liu, J. Wan, K. Zhou, "Cloud manufacturing service system for industrial-cluster-oriented application". J. Internet Technol, no.15 (3), pp. 373-380, 2014.

[7] Christiane Gebhardt, "The transfer of corruptive routines from old industrial regions to innovation clusters: a blind spot in innovation studies," A Journal of University-Industry-Government Innovation and Entrepreneurship, 2017. [Online]. Available: https://triplehelixjournal.springeropen.com/articles/10.1186/s40604-0170046-0. Accessed on: June, 27, 2019
[8] Hilary Cheng, Ming-Shan Niu, and Kuei-Hsien Niu, "Industrial cluster involvement, organizational learning, and organizational adaptation: an exploratory study in high technology industrial districts," Journal of Knowledge Management, no. 18 (5), pp.971-990, 2014. [Online]. Available: https://doi.org/10.1108/JKM-06-2014-0244._Accessed on: June, 28, 2019.

[9] Raisa Kozhukhivska, Nataliya Parubok, Nataliya Petrenko, Svitlana Podzihun, and Irina Udovenko, "Methods of assessment of efficiency of creating regional innovative clusters for dynamic development of economics," Investment Management and Financial Innovations, no. 14(3), pp.302-312, 2017. [Online]. Available: https://businessperspectives.org/images/pdf/applications/publishing/tem plates/article/assets/9512/imfi_2017_03cont2_Kozhukhvska.pdf. Accessed on: June, 29, 2019.

[10] Jiang Lan, Wang Chengjun, and Zhang Wei. "Investigation of the evaluation system of SMEs' industrial cluster management performance based on wireless network development," EURASIP Journal on Wireless Communications and Networking, 2019. [Online]. Available: https://jwcn-eurasipjournals.springeropen.com/articles/10.1186/s13638018-1318-8. Accessed on: June, 29, 2019.

[11] T. Sonobe, and O. Keijiro, Cluster-Based Industrial Development: An East Asia Model. New York: Palgrave MacMillan, 2006. [Online]. Available: https://www.researchgate.net/publication/252680045_Strategy_for_Clus ter-based_Industrial_Development_in_Developing_Countries.

[12] Sylvie Chetty, and Henrick Agndal, "Role of Inter-Organizational Networks and Interpersonal Networks in an Industrial District," Regional Studies, no. 42 (2), pp.175-187, 2008.

[13] V. E. Hoffman, G. S. C. Lopes, J. J. Medeiros, "Knowledge transfer among the small businesses of a Brazilian cluster," Journal of Business Research, no. 67 (5), May 2014. [Online]. Available: https://www.researchgate.net/publication/320738642_Knowledge_transf er_model_for_improving_productivity_of_the_cable_manufacturing_in dustry_A_South_African_perspective.

[14] European Innovation Scoreboard. [Online]. Available: http://www.eis.eu. Accessed on: June, 25, 2019

[15] V. Polterovich, Innovation and Imitation at Various Stages of Development: A Model with Capital. Moscow: New Economic School, Working paper, 2005.

[16] Country profiles (European Innovation Scoreboard) 2018. [Online]. Available: https://ec.europa.eu/docsroom/documents/30670.

[17] The global competitveness report 2018. [Online]. Available: https://www.weforum.org/reports/the-global-competitveness-report2018. Accessed on: June, 29, 2019

[18] Cluster observatory. [Online]. Available: http://www.clusterobservatory.eu. Accessed on: June, 29, 2019

[19] I.Ye. Verner, Ukraine in figures 2017. Statistical collection. Kyiv, 2018.

[20] L. Martínez-Cháfer, F. Xavier Molina-Morales, J. Peiró-Palomino, "The cluster is not flat. Uneven impacts of brokerage roles on the innovative performance of firms", Business Research Quarterly, no.21, pp.11-25, 2018.

[21] The Global Innovation Index 2017. Innovation Feeding the World. [Online]. Available: https://www.globalinnovationindex.org/userfiles/file/reportpdf/gii-fullreport-2017.pdf.

[22] D. D. Fundeanua, C. S. Badele, "The impact of regional innovative clusters on competitiveness", Procedia - Social and Behavioral Sciences, no.124, pp. 405 - 414, 2014.

[23] Verkhovna Rada of Ukraine. Law of Ukraine, 1999, About the special regime of innovation activity of technological parks. [Online]. Available: http://zakon2.rada.gov.ua/laws/show/991-14.

[24] A. Wasiluk, "Pro-innovative Prerequisites for Establishing the Cooperation between Companies (in the Perspective of Creation and Development of Clusters)", Procedia Engineering, no.182, pp. 755-762, 2017. 